\title{
Die aard van die geloofsgemeenskap in Nehemia 9
}

\section{P M Venter \\ Universiteit van Pretoria}

\begin{abstract}
The character of the community of faith in Nehemiah 9

In this study the prayer in Nehemiah 9:5b-37 is compared with Psalm 106 and investigated within its literary and social context. The conclusion is reached that the community of faith portrayed in this prayer is a cultic community standing in a relationship with God which expresses its guilt as well as its firm belief in God's power to change its circumstances.
\end{abstract}

\section{NEHEMIA 9 EN PSALM 106}

Die gedig in Nehemia 9:5b-37 kan as 'n 'hymn' (Fensham 1982:228), 'sermonic prayer of confession' (Throntveit 1992:102 en 106), of 'grosse Bussgebet' (Gunneweg $1987: 124)$ beskryf word. Dit is nie net 'n gebed tot God nie, maar dit is tegelyk ook 'n oproep tot die geloofsgemeenskap van Jerusalem. Die gedig is volgens Throntveit (1992:102) konsentries gestruktureer:

\section{A: Lofprysing (5b)}

B: Belydenis in die vorm van historiese retrospeksie (6-31)

$\mathrm{X}$ : Versoek (32)

$B^{1}$ : Belydenis van teenswoordige sonde (33-35)

$A^{1}$ : Klaaglied (36-37).

In die belydenis van teenswoordige sonde $\left(B^{1}: 33-35\right)$ en die klaaglied $\left(A^{1}: 36-37\right)$ gaan dit om die identifisering van die huidige geslag met dié van die verlede wie se geskiedenis hier vertel word (B:6-31). Hierdeur word die solidariteit van die huidige geloofsgemeenskap met die Israel van voor die ballingskap betuig (vgl Throntveit 1992:103).

Die belydenis in 6-31 neem die vorm aan van 'n historiese terugblik op die geskiedenis van die volk Israel. Die selfde benadering kom ook voor in Psalms 78, 105, 106, 135 en 136. Volgens Fensham (1982:228) het hierdie Psalms óf 'n dankbetuigingstema óf ' $\mathrm{n}$ boetedoeningstema. Psalm 106 het 'n boetedoeningstema en die res 'n 
dankbetuigingstema. Die gedeelte in Nehemia 9 het ook 'n boetedoeningstema. Dit maak dit noodsaaklik om Psalm 106 met verse 6-31 en met die res van die gedig in Nehemia 9 te vergelyk.

Volgens Throntveit (1992:103) is Nehemia 9:6-31 saamgestel volgens die skema Skepping-Abraham-Eksodus-Wildernis-Israel in die land. Hierdie skema, of dele daarvan, kom ook voor in die ander gedigte wat 'n historiese terugblik op die geskiedenis van Israel gee:
BOETE-
DANK-
liedere
liedere

$\begin{array}{llllll}\text { Neh } 9 & \text { Ps } 106 & \text { Ps } 78 & \text { Ps } 105 & \text { Ps } 135 & \text { Ps } 136\end{array}$

\begin{tabular}{|c|c|c|c|c|c|c|}
\hline $\begin{array}{l}\text { Skep- } \\
\text { ping }\end{array}$ & 6 & & & & & $5-9$ \\
\hline $\begin{array}{l}\text { Aarts- } \\
\text { vaders }\end{array}$ & $7-8$ & & $5-8$ & $5-25$ & $4-7$ & \\
\hline $\begin{array}{l}\text { Uittog- } \\
\text { gebeure }\end{array}$ & $9-11$ & $7-12$ & $\begin{array}{l}12-13 \\
43-51\end{array}$ & $26-38$ & $8-9$ & $10-15$ \\
\hline $\begin{array}{l}\text { Woestyn- } \\
\text { tog }\end{array}$ & $12-21$ & $13-33$ & $\begin{array}{l}14-42 \\
52-53\end{array}$ & $39-44$ & $10-12$ & $16-24$ \\
\hline $\begin{array}{l}\text { Die } \\
\text { land }\end{array}$ & $22-31$ & $34-42$ & $54-72$ & & & \\
\hline
\end{tabular}

Alhoewel daar meer gemeenskaplikes ten opsigte van hierdie skema tussen Psalm 78 en die betrokke gedeelte in Nehemia 9 voorkom, staan Psalm 106 om twee redes nader aan die Nehemiateks as Psalm 78. Albei is boeteliedere, terwyl Psalm 78 'n danklied is. Verder bevat Psalm 106:43-47 verwysings na die terugkeer uit die ballingskap, wat nie in Psalm 78 voorkom nie, maar wel in Nehemia 9:32-37. Die doksologie in Psalm 106:1 en die verwysing na die Israeliete as die uitverkorenes van God in vers 5, gee 'n aanduiding dat die psalm betreklik jonk is (vgl Booij 1994:349) en uit die tyd na die ballingskap kom. Verwysing in vers 46 na medelye wat gevind is by hulle by wie die volk gevangenes was, en verwysing in vers 47 na God wat sy volk moet bymekaar maak tussen die volke uit, dui die situasie van die diaspora en die terugkeer uit die bal- 
lingskap aan. Dieselfde tydperk word in Nehemia 9:32-37 aangedui. Daar word om God se genade vir die haglike omstandighede van die tyd na die ballingskap gepleit. Hierdie gemeenskaplike tema en tyd is 'n verdere rede om die twee eenhede met mekaar te vergelyk. Veral die vergelyking van die motiewe agter die pleitredes in die twee eenhede gee belangrike inligting oor die selfbeskouing by Israel in die tyd na die ballingskap.

\section{PSALM 106}

Psalm 106 is 'n skuldbelydenis. Israel word hier uitgebeeld as die een wat geslag op geslag skuldig is aan ontrou en ongehoorsaamheid aan God. Hulle het die groot reddingsdade wat God verrig het, in die wind geslaan en dit gou weer vergeet. Hulle het hulle teen Moses en teen God verset. Hulle het die heidene se afgode aanbid en aan hulle offers gebring. Ook die huidige geslag maak hulle aan dieselfde oortreding skuldig. God, daarenteen, het die volk by herhaling in die geskiedenis gered ter wille van sy verbond met hulle en vanweë sy liefde vir hulle (vers 45). Die historiese gebeure word in hierdie psalm so vertolk dat dit lei '... tot 'n geskiedenisstruktuur wat die kontras beklemtoon tussen die liefde, redding en bevryding van die kant van Jahwe enersyds, en die sonde, verset en uittarting van die kant van Israel andersyds' (Oberholzer 1988:385). Soos dit dikwels die geval in boetegebede is (vgl Booij 1994:348), ontwikkel die skuldbelydenis hier uit die lofprysing waarmee die psalm begin en eindig. Dat skuldbelydenis en lofprysing naas mekaar staan, dat dieselfde geskiedenis getuig van die eer van God en tegelyk van die oneer van sy volk, is bepalend vir die identiteit van Israel:

Die individu wat deel in die liturgie, vind sy identiteit in sy gemeenskap met die Godsvolk, en die Godsvolk op sy beurt vind sy identiteit in sy gebed om redding, 'n gebed wat voortkom uit die belydenis van die dade van God in teenstelling met die dade van die volk soos dit in die geskiedenis vertoon word.

(Oberholzer 1988:386-7)

Die bede in vers $\mathbf{4 7}$ om redding, sodat Israel God se heilige Naam kan loof en hulle in die lof aan God kan verheug, vorm die kern van die gedig (vgl Oberholzer 1988:386) en dui tegelyk die program aan in terme waarvan Israel hulle eie identiteit kan verstaan.

\section{NEHEMIA 9}

Wanneer daar in Nehemia 9 belydenis van skuld gedoen word, kom daar ook ander elemente by. In verse 6-31 (Throntveit se gedeelte B waar die belydenis die vorm van historiese retrospeksie aanneem) word die oortreding van Israel ook soos in Psalm 106 
in terme van hardkoppigheid, versuim om aan God gehoorsaam te wees en 'n neiging om God se verlossingdade te vergeet, gedefinieer. Wat egter anders is as in Psalm 106 , is dat die skuld hier uitgedruk word in terme van Israel se versuim om die bepalings, wette, voorskrifte en gebooie wat God aan hulle gegee het, te gehoorsaam (verse 13-14, 16, 29). Hierdie gebruik van wetsterminologie '... erklärt sich unschwer aus der Zielsetzung des ganzen Psalms und seines Kontextes: Vor allem das Gesetz hat Israel verstossen, also muss auch mit soviel Worten von dem Gesetz als von Jahwes gnädiger Gabe zum Leben gesprochen werden' (Gunneweg 1987:126). 'n Tema wat hier voorkom en nie in Psalm 106 nie, is dat hulle God se profete doodgemaak het (verse 26 en 30). Dieselfde is die geval met die tema van die land (vgl Throntveit 1992:104). God kom sy belofte na om die land wat Hy aan Abraham beloof het, aan sy nageslag te gee (verse $8,15,22-26$ ).

Verse 33-35 (Throntveit se gedeelte $B^{1}$ waar belydenis van teenswoordige sonde gedoen word) '.. is a virtual summary of the confession in verses 6-31 ...' (Throntveit 1992:105). Dit is nie net duidelik uit wat Throntveit (1992:105) 'verbal parallels' tussen die twee dele (soos 'regverdig', 'reg gedoen', 'waarsku') noem nie, maar veral uit die definiëring van skuld in terme van die wet van God, sy gebooie en sy verordeninge wat die volk nie nagekom het nie. Ook wanneer God se optrede teenoor dié van die volk gestel word, word dit in die selfde wetsterme uitgedruk as 'reg' en 'regverdig'.

In die Klaaglieddeel (verse 36-37) word die tema van die land opgeneem om nie net die solidariteit van die huidige geslag met die skuld van die vorige geslag uit te druk nie, maar ook die nood van die hede te skets. God het die land wat Hy belowe het, aan die volk gegee om die vrug daarvan te gebruik, maar daar het ' $n$ ironiese draai gekom: die volk bly in hulle land, maar hulle is slawe in die land wat die opbrengs daarvan aan vreemde oorheersers moet afstaan. Rondom die temas van God se instellings en die land wat Hy gegee het, word die volk se identiteit geskets in terme van mense wat aangekla staan van wetsverbreking en ontrou en in die ironiese ellende verkeer van besitters van die land wat geen sê in hulle eie land het nie. Terwyl God sy verbond en sy troue liefde in stand hou, staan sy volk in skuld en slawerny voor Hom. In hierdie slotgedeelte (verse 32-37) kom dan '... das eigene Anliegen des Verfassers zur Sprache ...' (Gunneweg 1987:129). Soos die bede om redding in Psalm 106:47 die kern van die gedig daar vorm en die program aandui in terme waarvan Israel hulle eie identiteit kan verstaan, vorm die bede in vers 32 die samevatting van verse 33-37 en die '... structural heart of the passage ...' (Throntveit 1992:106) van Nehemia 9:5b-37. Dit gee die restourasieprogram aan waarvolgens die geloofgemeenskap in terme van wet en land in die tyd na die ballingskap hulleself weer kan opbou (vgl Gunneweg 1987:129). 


\section{DIE NARRATIEWE KONTEKS}

Teenoor Blenkinsopp (1988:301), wat hierdie gebed los van sy konteks wil lees as '... an aspiration toward political emancipation as a necessary precondition for the fulfillment of the promises ...' (Blenkinsopp 1988:308), wil ons dit as integrale deel van die omringende konteks lees. Die lied vorm die logiese uitvloeisel van die vertelling in Nehemia 9:1-5a. Dit is 'n 'gemeentelied' (Gunneweg 1987:124) waarin '... die zur Busse in Sack und Asche Versammelten selbst mit einem Busslied zu Worte kommen ...' (Gunneweg 1987:124).

Eskenazi (1988:96-7) lees dit binne die omraming van Nehemia 8:1-10:40. Dit gaan volgens haar in hierdie afdeling oor die aanvaarding en die implimentering van die Tora in die sentrale posisie van die gemeenskapslewe. Daar vind drie byeenkomste plaas (8:1-12, 8:13-18, 9:1-37) wat uitloop op 'n geskrewe onderneming van die gemeenskap om hulle by die Wet van God te hou $(10: 1-40)$. Soos in die res van die Esra-Nehemia vertelling, meen sy dat ook in hierdie gedeelte die drieledige tema van Wet van God, volk van God en huis van God 'n leidinggewende rol speel. Wanneer die Tora by die derde byeenkoms (9:1-37) gelees word, loop dit uit op die lang gebed wat in 9:5b-37 staan. Sy lei uit die aard van die vorige byeenkomste af dat hierdie gebed deur die gemeenskap in geheel uitgespreek is (vgl Eskenazi 1988:100). Die gebed beklemtoon die sentrale rol van die gemeenskap op verskillende maniere, onder andere deur die kennis van die volk van hulle eie tradisie, soos dit in die gebed reflekteer word, en hulle bereidheid om uit hierdie Toratradisie te leer: '.. the people demonstrate a new competence, a new understanding of what they have read, and prove able to translate these into commitment and action' (Eskenazi 1988:101). Hoewel die tema van wat Eskanazi 'die huis van God' — bedoelende die huishouding van God, die geloofsgemeenskap - noem, nie pertinent in hierdie gedeelte voorkom nie, loop die byeenkomste wel op ' $n$ hernude toewyding van die gemeenskap aan die Tora uit.

Eskenazi lees hierdie gebed binne die konteks van wat sy as die derde hoofdeel (8:1-13:31) van die Esra-Nehemiaverhaal beskou. Sy gee aan hierdie gedeelte die opskrif 'Succcess (Objective Reached): The Comunity Celebrates the Completion of the House of God According the Torah' (Eskenazi 1988:95). Die opdrag van die Here om sy huis te voltooi, is uitgevoer. Die eerste fase van hierdie grand finale is die 'Consolidation according to Torah' (Eskenazi 1988:95) in 8:1-10:40.

Throntveit (1992:7) beskou Nehemia 7:73b-10:39 ' $\ldots$ as a unit that culminates in the people's response to the law and focuses our attention on the renewal of the congregation ....' Hierdie eenheid bestaan volgens Throntveit uit drie tonele: 7:73b-8:12, 8:13-18 en 9:1-10:39 wat elkeen volgens dieselfde volgorde en patroon saamgestel is. Daar is telkens verwysing na 'n bepaalde tyd, gevolg deur besonderhede van 'n by- 
eenkoms wat plaasvind. Daarop volg elke keer 'n geleentheid waarop die wet voorgehou word, waarop weer 'n toepassing ('application'; vgl Throntveit 1992:7) en 'n reaksie van die vergadering volg. Die gebed $(9: 4-37)$ in die derde toneel $(9: 1-10: 39$; teenoor Eskenazi wat die toneel beperk tot 9:1-37 en 10:1-40 apart stel en as reaksie op al drie die byeenkomste beskou) beskou Throntveit as die 'application' van die gebeurereeks. Dit het dieselfde funksie as wat die verduideliking van die wet (8:7-11) in die eerste toneel $(7: 73 \mathrm{~b}-8: 12)$ en die bestudering van die inhoud van die wet $(8: 14$ $15)$ in die tweede toneel (8:13-18) het. Dit gaan in die toepassing van die wet wat gelees is (hier in toneel drie in die vorm van ' $n$ lang gebed) om die bedoeling '.. to represent the pattern of Israel's traditional story as that of the restoration community ...' (Throntveit 1992:100). Die identiïisering van die nuwe gemeenskap met die ou Israel het egter die doel om 'n bepaalde reaksie uit te lok. Dit gaan daarom '.. to motivate the people into making the proper response so woefully lacking in the historical survey ...' (Throntveit 1992:106).

Volgens ons analise hierbo en die vergelyking wat ons met Psalm 106 getref het, bestaan die solidariteit van die huidige gemeenskap met die tradisionele gemeenskap van Israel nie net in hulle gemeenskaplike sondigheid voor God nie, maar nader bepaald, in hulle versuim om die voorskrifte van God te gehoorsaam. Die besit van die land het by hulle die ironiese wending geneem dat hulle onderdane van ' $n$ vreemde moontheid op hulle eie werf geword het. As die byeenkomste dan volgens Eskenazi op 'n plegtige onderneming uitloop om die Tora te onderhou en volgens Throntveit op 'n reaksie, van vernuwing van die gemeenskap, dan moet in die lig van ons ondersaek meer gesê word oor die aard van hierdie onderneming wat uitgelok word en hierdie projek om die gemeenskap te rekonstrueer.

Hierdie projek is 'n saak wat afspeel rondom die bewustheid van die noodsaak om God se voorskrifte te eerbiedig en die noodsaak van die uitkoms wat Hy moet gee uit die ironiese nood waarin die volk verkeer. Die beklemtoning in die toepassing van die wet van ongehoorsaamheid aan God se bepalings, die ironiese uitkoms van hierdie ongehoorsaamheid en die totale afhanklikheid van God wat nooit nagelaat het om sy verbond en troue liefde in stand te hou nie, bepaal die denkraamwerk van waaruit die gemeenskap moet leer lewe en die identiteit wat hulle moet uitbou. Berou oor eie swakheid en vreugde oor die onbegrensde trou en liefde van God, vorm twee interaktiewe komponente wat in die selfbewussyn van hierdie gemeenskap hulle voortstu na voortdurende besinning en voortgaande transformasie.

\section{DIE SOSIALE KONTEKS}

Hierdie transformasie kan vanuit die sosio-kulturele antropologie as 'n proses van kulturele heropbou ('cultural revitalization') gesien word. Die studie van Tollefson \& Williamson (1992), aan die hand van die model van Wallace, oor die uitwerking van 
vreemde oorheersing, beplande verandering en gevolglike kulturele herstrukturering, is hier van insiggewende belang. Volgens Wallace se model van sosiale verandering vind daar in die vierde fase van hierdie proses ses dinge plaas:

* Die leier of hervormer raak oortuig dat die wantoestande in die gemeenskap te wyte is aan die oortreding van bepaalde reëls en dat herstel kan plaasvind mits bepaalde voorskrifte gevolg word en bepaalde rituele uitgevoer word;

* hy begin hierdie visie in die openbaar propageer as die oplossing vir ' $n$ 'siek' gemeenskap wat sake sal herstel. Die volgelinge wat hy tot sy standpunt oorhaal, begin self ook om sy visie aan ander te propageer;

* die 'bekeerdes' word in 'n effektiewe organisasie saamgesnoer wat hierdie visie in hulle mini-gemeenskap begin uitleef;

* in die aanpassingsfase word die groep met ander bestaande groepe gekonfronteer en in hierdie proses ondergaan die oorspronklike visie die nodige aanpassings om dit vir die breë gemeenskap aanvaarbaar te maak;

* in die kulturele transformasiefase aanvaar die gemeenskap die visie wat aan hulle voorgehou is en implementeer dit met behulp van verskillende programme wat gevolg word - hoewel sommige van hierdie programme kan misluk, slaag ander weer daarin om die aanvanklike wantoestande wat tot die visie aanleiding gegee het, uit die weg te ruim; en

* roetinering volg indien die beweging daarin slaag om teenstand in die gemeenskap te oorkom, spanning op individuele en sosiale vlakke te verlig en die visie realisties by omstandighede aangepas word - die visie word dan deel van die daaglikse lewenspatroon van mense en word deel van die ekonomiese, sosiale, politieke en godsdienstige lewe van die gemeenskap.

Tollefson \& Williamson (1992:49) is van oortuiging: 'there seems to be a remarkable similarity between the six phases within the revitalization stage and the sequence of events within the Nehemiah story'. Nehemia 7:5-10:39 stem met die vyfde fase, die van kulturele transformasie ooreen. Hoewel die muur op hierdie stadium reeds voltooi was, die hekke ingesit is en die nuwe administrateurs aangewys was, was die basiese probleem van die Jerusalemgemeenskap nog nie opgelos nie. Die gemeenskap was steeds vervreem van hulle kulturele erfenis en losgesny van hulle geestelike wortels. So lank daar nie kulturele transformasie plaasvind nie, sou die gemeenskap geen ideaal hê om na te streef of enige iets om hulleself aan te verbind nie. Wat in Nehemia 8-10 beskryf word, is die '.. religious reordering of the community of faith ...' (Tollefson \& Williamson 1992:56). 'n Radikale verandering vind hier in die etos van die gemeenskap plaas. 'n Hersiene stel waardes en simbole word hier geïmplementeer. In 
Nehemia 8 maak die gemeenskap hulle los van die bestaande etos, in hoofstuk 9 beweeg hulle na 'n nuwe etos en in hoofstuk 10 verbind hulle hulleself aan die nuwe etos. Drie metodes om groepsverandering teweeg te bring, kom in Nehemia 9 aan die lig: 'n publieke byeenkoms om die mense bymekaar te kry (9:1-3); verhoging van kulturele dissonansie tot ' $n$ onhoudbare vlak (9:6-35); opskerping van ontevredenheid by die publiek (9:36-37). Die openbare gebed in 9:6-35 moes volgens Tollefson \& Williamson (1992:57) die intensiteit van kulturele dissonansie verhoog deur die ongelykheid wat daar bestaan tussen oortuigings en omstandighede uit te wys. Die gebed beklemtoon die dispariteit tussen die historiese oortuigings van die gemeenskap en hulle teenswoordige sosiale omstandighede. 'It focuses upon the discrepancies between the people's beliefs, the past behaviour of the nation and the present circumstances, with the basic inconsistencies being described, applied and intensified ...' (Tollefson \& Williamson 1992:58). Die ontevredenheid wat deur die gebed aangevuur is, word tot 'n hoogtepunt gevoer wanneer daar in die slotgedeelte (9:36-37) gewys word op die nasionale katastrofe van ekonomiese bankrotskap, politieke onderhorigheid aan 'n vreemde moondheid in hulle eie land en belasting wat hulle aan 'n buitelandse moondheid moet betaal. Dit gee die finale deurslag om die gemeenskap te motiveer om 'n nuwe etos te aanvaar. Die gebed bied egter ook hoop vir die mense deur te beklemtoon dat God genadig, geduldig en vergewensgesind is. Berou en gebed het in die verlede die loop van gebeure verander en dit kan weer in die hede gebeur (vgl Tollefson \& Williamson 1992:58).

Tollefson \& Williamson mis egter in hulle analise die punt van identifisering tussen die teenswoordige gemeenskap en die Israel van ouds. Die dispariteit tussen oortuiging en omstandighede is daarin geleë dat die gemeenskap nie voldoende identifiseer met die geslag van die verlede en nie besef dat die haglikheid van hulle omstandighede te wyte is aan hulle eie ongehoorsaamheid aan die verordeninge van God nie. Deur hulle opnuut aan God en sy gebooie toe te wy, deur hulleself in solidariteit met die sonde van die voorgeslag in afhanlikheid voor God te stel, word 'n ou etos heringestel en onder nuwe omstandighede van politieke afhanklikheid opnuut geaktiveer. Ackroyd is nader aan die waarheid wanneer hy dit sien as ' $n$ tyd wat in die verhouding staan van kontinuiteit-diskontinuiteit: ' $\ldots$ the later community needed to be assured that the contemporary experience could be seen to cohere with the past, representing a revision of its values but a continuity with them ...' (Ackroyd 1991:134). Dit is volgens hom 'n tyd van konsolidasie: 'It attempts interpretation of historic experience, particularly that of exile and restoration, seeing in the acceptance of judgment and the purification by exile a way through the future, or seeing in the continuous character of ancient tradition a link with the past and a way of life for the present' (Ackroyd 1991:85). 
In Esra-Nehemia probeer die outeur - noem hom die Kronis, bedoelende 'n bepaalde denkskool, ' $n$ lid van 'n bepaalde groep binne die gemeenskap, of moontlik ook die kreatiewe denke van 'n leidinggewende individu binne so 'n groep wat ongeveer 350 v C leef (vgl Ackroyd 1991:276) — om 'n sentrale konsep van die aard van die Joodse geloofsgemeenskap, van sy teologie en van die betekenis van sy ryk en geskakeerde tradisies an te bied. Hy besin in sy werk oor hoe die klein Joodse gemeenskap, wat aan Persiese oorheersing onderworpe is, '.. was to think of itself as the true heir to the past traditions and to express its position rightly in worship and obedience ...' (Ackroyd 1991:280). Hy probeer 'n patroon aanbied vir die inwoners van Jerusalem wat hulle kan leer hoe om godsdiensgemeenskap te wees binne die konteks van 'n volk wat onderhorig is, wat in 'n uiters delikate politieke situasie verkeer, wat gesentreer is in die klein area van Jerusalem en Juda, en sterk bewus is van die verlede van hierdie groep en bedagsaam is op die eise wat aan hulle as godsdiensgemeenskap gestel word.

Die basiese beskouing van die Judese gemeenskap is dat hulle die mense is wat aan die provinsie Juda behoort en uit die ballingskap teruggekeer het (Esra 2 en Nehemia 7). In Esra 4:1-5 word die gemeenskap beperk tot dié wat die opdrag van Kores gekry het om die tempel te herbou. Vanweë die traumatiese ervaring van die ballingskap en die politieke omstandighede van die Persiese ryk, het daar 'n bepaalde verandering in die aard van die gemeenskap en hulle selfverstaan ingetree. Hierdie verandering kan nie op simplistiese wyse beskryf word as die oorgang van 'n nasie na 'n kerkgroep nie. Dit is geen oorgang van ' $n$ politieke na ' $n$ non-politieke entiteit nie. Juda is na die ballingskap ' $n$ provinsiale eenheid binne die Persiese ryk wat as administratiewe eenheid 'n eiesoortigheid het en beperkte politieke mag beoefen. Religieuse elemente begin al meer die voortou neem om die aard van die gemeenskap te bepaal. Hierdie nuwe restorasiegemeenskap kan as 'n 'res', 'seuns van die ballingskap' (Esra 4:1), en slegs in 'n sekere $\sin$ as hulle wat geroep is, beskryf word, maar nie summier as 'n kerk, 'n $\dot{\varepsilon} \kappa \kappa \lambda \eta \sigma i \alpha$ nie (vgl Ackroyd 1991:133-134). Hier is eerder sprake van 'n nuwe definisie waarna nog gesoek word - 'n definisie wat wegbeweeg van een waar identifikasie tussen politiek en godsdiens iets vanselfsprekend was, na een wat die gemeenskap meer in terme van die godsdiens wil sien.

Tollefson \& Williamson is korrek dat daar 'n gevoel van kulturele dissonansie was. Volgens Ackroyd word daar in die gebedspsalms van Esra 8 en Nehemia 9 in algemene terme gereflekteer op die omstandighede van die gemeenskap. 'Here all the tension between political distress and religious awareness is brought to a head' (Ackroyd 1991:286). Die onderdanige posisie van die gemeenskap word as '... a condition of distress ...' (Ackroyd 1991:203) beleef. Nehemia 9 '... suggests another aspect of 
Jewish response to the current political and social situation. Living as a subject people is by no means to be regarded as an ideal state' (Ackroyd 1991:204). Wanneer daar dan gepoog word om uit hierdie dissonansie weg te beweeg, impliseer dit nie 'n radikale breuk met die verlede nie. Die gemeenskap koester ideale waardeur die lede hulle identiteit wil behou, maar dit in nuwe bane wil stuur. Ackroyd merk hier tereg op: 'Such a projection into the future is not to be depicted solely in terms of disappointment in the present; it may rather be seen as a way of speaking of total hope and restoration, of a resolution of the theological problems of the present, by a confident statement of who God is and how he acts' (1991:238). Die gemeenskap soek 'n toekomsidentiteit in terme van die God met wie hulle in die verlede in 'n verhouding gestaan het. Een manier waarop hierdie strewe na identiteit tot uitdrukking gebring is, is deur dit met die wet van God te identifiseer - soos dit in Nehemia 8 en verder tot uitdrukking kom: 'It is a community ... which responds in distress and rejoices to the reading and exposition of the law, revealing a deepened religious consciousness' (Ackroyd 1991:233-4). Dit het 'n bykans tweeslagtige aard waarin vreugde en smart, hoop op God en skuldbelydenis voor God sy aan sy staan: 'There is a combination of that theological strand which lays emphasis on humanity's obligation to obedience and faith, with its complement - which sees the inability of humankind to respond exemplified in judgment and met by divine grace' (Ackroyd 1991:283).

Die fase van kulturele transformasie word bereik wanneer die godsdiensgemeenskap in Jerusalem skriftelik onderneem om die voorskrifte en bepalings van God te gehoorsaam (Nehemia 10). Die praktiese beslag wat hulle aan hierdie onderneming gee, is ' $n$ belofte om ses dinge te doen. Hulle het belowe (1) om nie met heidene te ondertrou nie (10:30); (2) om die sabbatdag te onderhou (10:31); (3) om elke sewende jaar die sabbatsjaar te onderhou (10:31); (4) om tempelbelasting te betaal $(10: 32,33)$; (5) om hout vir die brandoffers in die tempel te voorsien (10:34), en (6) bydraes vir die tempel te gee (10:35-39). Dit kom neer op drie dinge: om godsdienssuiwerheid in stand te hou, die feeste te hou en die tempelkultus in stand te hou. In hierdie aktiwiteite vind die godsdiensgemeenskap die geskikte uitingsvorms vir hulle tyd en omstandighede om beslag te gee aan die identiteit wat hulle vir hulleself uitgemaak het by die lees en nadenke oor die wet.

\section{I EN II KRONIEKE}

Die kultus is ' $n$ gemeenskaplike faktor tussen Esra-Nehemia en die Kroniekeboeke en dui op ' $n$ ideologiese ooreenkoms tussen die twee werke (vgl Eskenazi 1988:21-34). Indien ons saam met Nel (1991:108) aanvaar dat 1 en 2 Kronieke '... 'n veel later tydperk in die post-eksiliese geskiedenis uit[beeld] as wat die geval is met die boeke Esra 
en Nehemia ...', en dat die Kronis, soos reeds hierbo gedefinieer, '... has used EzraNehemiah apart from the quotation in 2 Chron 36.22-23 ...' (Riley 1993:23), kan ons aanneem dat die gedagtes rondom die godsdiensgemeenskap as kultiese gemeenskap daar 'n ent verder ontwikkel sou word. Volgens Nel gaan dit vir die Kronis in Kronieke om 'n teokrasie. Die kernmomente in hierdie teokrasie is die God wat regeer en die volk wat uitverkies is om regeer te word. Die verhouding tussen hierdie twee kernkomponente bepaal die aard van die teokrasie. In hierdie verhouding is Jahwe die onveranderlike kernkomponent, terwyl die volk die veranderlike komponent uitmaak. Die veranderlike komponent 'volk' is weer saamgestel uit drie funksionerende elemente: qahal, kultus en koning.

Die volksbyeenkoms kwalifiseer vir die Kronis alleenlik '... as 'n Kahal indien Dawidiese leierskap of koningskap en ' $n$ kultiese of religieuse doelwit aanwesig is ...' (Nel 1991:114). Die teokrasie is dus daar in aksie waar God in verhouding staan tot die volksbyeenkoms wat as qahal gekonstitueeer is, onder Dawidiese leiding staan en 'n kultiese oogmerk het.

Omdat die koningskap in die tyd van die Kronis nie meer bestaan nie, vereenselwig hy koning en kultus met mekaar en skets die historiese doel van die koningskap as die daarstelling en instandhouding van die kultus. Volgens Riley (1993:156) ‘ ... emerges (the cultus) as a principle reason for the monarchy's very existence and takes presedence over the Davidic monarchy as the real concern of the Chronicler'. Die tempel en die kultus is vir die Kronis die standhoudende nalatenskap van die huis van Dawid. Hulle wat aan die Jerusalemse kultus deelneem, vorm vir die Kronis die ware Israel (vgl Ackroyd 1993:191).

Die godsdiensgemeenskap staan dus as kultiese qahal voor God in Kronieke. Wat in Esra-Nehemia as die 'huis van God' uitgebeeld is, word in Kronieke as die qahal van Jahwe voorgehou (vgl Nel 1992:357). Hierdie qahal as veranderlike komponent van die teokrasie is egter altyd 'n geloofsgemeenskap wat deur God herskep, herinsti-

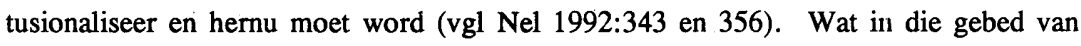
Nehemia 9 gesê is, geld van die werke van Esra-Nehemia en Kronieke in die geheel. Die ineenvlegting van lof aan God en belydenis van eie skuld in sigbare beleefbare vorm, is die kenmerk van die geloofsgemeenskap wat hier uitgebeeld word.

\section{Literatuurverwysings}

Ackroyd, P R 1991. The Chronicler in his age. Sheffield: JSOT. (JSOT Supplement Series 101.)

Booij, T H 1994. Psalmen, deel III (81-110). Callenbach: Nijkerk.

Blenkinsopp, J 1988. Ezra-Nehemiah: A commentary. London: SCM Press. 
Eskenazi, T C 1988. In an age of prose: A literary approach to Ezra-Nehemiah. Atlanta: Scholars Press.

Fensham, F C 1982. The books of Ezra and Nehemiah. Grand Rapids: Eerdmans.

Gunneweg, A H J 1987. Nehemia. Gütersloh: Gerd Mohn. (KAT Band XIX 2.)

Nel, H W 1991. Die Kronis se uitbeelding van die teokrasie in 1 en 2 Kronieke. DLitt et Phil-proefskrif, Universiteit van Suid-Afrika.

- 1992. The Qahal in 1 and 2 Chonicles, in Wessels, W \& Schefler, E (eds), Old Testament science and reality: A mosaic for Deist. Pretoria: Verba Vitae.

Oberholzer, J P 1988. Opmerkings oor die teologie van Psalm 106. HTS 44/2, 380387.

Riley, W 1993. King and cultus in Chronicles: Worship and reinterpretation of history. Sheffield: JSOT Press. (JSOT Supplement Series 160.)

Tollefson, K D \& Williamson, H G M 1992. Nehemiah as cultural revitalization: An anthropological perspective JSOT 56, 41-68.

Throntveit, M A 1992. Ezra-Nehemiah. Louisville: John Knox. 